\title{
Region, innovation and knowledge in strategy of European Union economic growth and social security
}

\section{Introduction ${ }^{1}$}

The adjustment in the European Union to the global economies challenges is progressing. Financial market situation has improved on the back of the steady implementation of the reform agenda, including the advancements in the European Monetary Union (EMU) architecture, and by the important policy decisions in the euro area, including by the European Central Bank (ECB). The significant reform efforts in the vulnerable Member States are also bearing fruit: leveraging has decreased in the private and public sectors and competitiveness is improving in countries with large competitiveness gaps creating conditions for further adjustment going forward. Exports are contributing increasingly to improvements in large current account deficits, which bodes well for the lasting nature of the correction. The large growth differences among the EU countries are also a reflection of the ongoing adjustment: temporarily lower or negative growth is often a feature of deep adjustments, but they open the way for more sustainable growth and convergence.

\section{Research and methodology}

The main objective of the research task is to give analysis of the region, innovation and knowledge in strategy of the European Union economic growth and social security. To the particular goals of the research belong the presentation the innovation system and knowledge in the creation of enterpreneurship, theoretical concept of innovation system and innovation process at the level of the region, knowledge-based economy, constructed advantage, Triple Helix model constructed advantage, Europe 2020 strategy and Innovation Union and Horizon 2020 as the financial instrument implementing the Innovation Union.

The analized problems were solved with the use of both quantitative and qualitative research methods. The main research method applied in this analysis, was a method of scientific study used for splitting the whole (of individual items, their sets, phenomena) by means of logical abstraction. It was also used the analogy (comparative) method, which consists in finding similarities and differences between the items under study, the

1 Paper prepared in the framework of the Grant OPUS, Narodowe Centrum Nauki - NCN (National Centre of Science - NCS), Nr UMO - 2013/11/B/HS5/03572. 
documentation method and statistical methods. It were applied the descriptive method, as well as methods of descriptive statistics and forecasting. Additionally, it were used the methods of deductive and inductive forecasting.

\section{Discussion}

\subsection{Innovation system and knowledge in creation of enterpreneurship}

The economy is not only the institutions which create it (meaning entities), but also the results of synergies, which arise as a result of mutual cooperation. Therefore, apart from the institutions that generate knowledge and innovation (companies), the research-and-development sphere or intermediaries in the transfer of innovation in the concept that sees the importance of different interactions that occur between them. The innovation system consists therefore of institutions and relations between them, thanks to which the particular economy creates an efficient mechanism for the distribution of knowledge with a view to its further processing. A significant role for the efficiency of the innovation system plays the environment, especially the consumers of innovation, who create the demand. They are important in particular nowadays in the times of the market-driven economy. Companies monitoring the tastes of consumers, create new needs through innovations.

Also important for the efficiency of the innovation system is the infrastructure of the environment, meaning the legislation, and in particular the protection of intellectual property rights as well as the systems of education, financing and transport. A key feature of the systems is the historically established culture and the accumulation of knowledge and experience making their character unique. Moreover, for the efficiency of the innovation system as distributing knowledge, its openness to influences and knowledge from other systems and the interactions with them.

An efficient system also has to be fully developed, i.e. it should not be missing any needed elements. The system will be the system if its entities are linked, because the system is a ordered arrangement of elements, between which there are certain relationships which constitute a whole. Such a system will be as strong as its weakest link (Wójnicka, 2008).

Companies are a critical element in the innovation system, and their health determines the competitiveness of countries and social well-being. In the view of the new theory of economic growth developed by such researchers as Kenneth Arrow, Paul Romer and Robert Lucas, knowledge is the primary factor in determining productivity. According to the new theory of growth being the best theoretical foundation for the concept of the innovation system, the primary factor influencing the economic growth is the endogenous technical progress. In the endogenous theories workers are seen as an element capable of active interaction and creating changes in the production process, and therefore a huge role in increasing productivity is ascribed to human capital and knowledge.

P. Romer has enabled the analysis of learning process, noticing that thanks to the gained external benefits from it, the knowledge inspired by private investments be- 
comes publicly available. In addition, the latest examining of endogenous progress assumes that it is the result of investments by companies in the work of $\mathrm{R}+\mathrm{D}$. As Carlsson reckons every theory that is trying to endogenize the technological change must take into account the diversity of products, processes, economic entities and institutions. In addition, the interdependence of these different actors will be important, i.e. it must relate more to the system than individual units. From the perspective of the theory of growth based on the endogenous technological progress, the efficient innovation system - distributing knowledge, meaning accelerating the learning processes in the economy, will stimulate a higher general level of the particular economic development.

The concept of the innovation system emphasizes the cooperation as well as the flow of technology and information and various relationships and interactions between individual elements as a condition conducive to the success of the innovation process. OECD gives, among others, the following definitions of innovation systems derived from analyses on national innovation systems:

- the network of public and private sector, whose activities and interrelations initiate, import, modify and expand new technologies;

- the group of institutions which both together and individually contribute to the development and diffusion of new technologies, and creates a skeleton, within which the governments formulate and implement the policies influencing the innovation process; the system of interconnected institutions that create, store and transfer knowledge, skills and tools that define new technologies.

Innovation systems are tested at various levels. The majority of analyses are conducted on national innovation systems, since it is considered that the characteristics distinctive to individual nations most affect the distinctness of the innovation process in companies: the type and number of institutions and their behaviour (Wójnicka, 2008).

It must be also emphasise the role of organisational culture as a key feature for creating innovation - the often described "enterpreneurial spirit". Innovative firms provide frames and value systems that emphasise innovation as central of the company's mission and put their money literally where their mouth is. Encouraging innovation, however, is a complex balancing act that consists of three components: first, the balancing of goals which have to be linked to the corporate mission, but not be overly specific; second, the balancing of rewards through a system that recognises members' contribution, but does not encourage overly risky behaviour; and third, the balancing of time pressures (Greenberg, Baron, 2003, s. 536-538).

Innovative capacity within an organisation depends first on its ability to continuously learn and to subsequently modify its structures, processes, and practices, and second on the company's social capital. Innovating firms are learning organisations (see Argyris, 1982, 1999), which enable individual learning within their workforce. Indeed, "in the knowledge-creating company, inventing knowledge is not a specialised activity - the province of the $R \& D$ department or marketing or strategic planning. It is a way of behaving, indeed a way of being, in which everyone is a knowledge worker - that is to say an enterpreneur" (Nonaka, 1991, s. 97). Such learning processes not only enhance a firm's innovative potential but also increase efficiency and competitive advantage (Anheier, Fliegauf, 2013, s. 144). 
It must be emphasise that innovator attributes are certainly important but they are not all-important. Innovation does not happen in isolation, and Ruvinsky (2005) cautions us to be very of tales glorify the 'lone genius' - be it an individual or a cooperation. Instead, innovation is based on complex interrelationsship between an organisation and its larger environment(s) (Anheier, Fliegauf, 2013, s. 144).

\subsection{Theoretical concept of innovation system and innovation process at the level of the region}

The theoretical concept of the innovation system is a comprehensive look at the innovation process. Fumio Kodama points out that the existing categories of innovation and the measurements still do not cover all types of innovation. After Charles Freeman, he distinguishes, besides radical and improving innovations, other kinds of technological change like the change of the technological system and techno-economic paradigm. In the modern economy, the innovation can be realized by combining products and processes held by various companies from various sectors of the economy, as well as businesses and other entities, particularly from the field of research and development. In many industries new economy causes modularity of innovative activity. Innovations - their individual modules, are subcontracted to particular vendors, so that the company achieves flexibility and reduces costs (e.g. large automotive factory). The necessary response to the modularity of economy is a comprehensive approach to the innovation process.

Technological change, is now very fast, but often meets a deep inertia among social institutions. Innovations determining the competitiveness have not only technological dimension, but also the organizational and personal one - the quality of human resources is extremely important for the profitability and the development of an organization. Moreover, significant is the nature of the innovation process that is interactive and based on the cooperation. The today ground-breaking technologies are so complex that individual companies would not be able to develop them alone. Their complexity makes it impossible to understand all the details by a single expert, as well as the knowledge on this topic may not be fully and thoroughly transferred to the other people.

Managers of many successful companies often are ashamed to admit that they cannot understand the reasons for the success of their corporations. Usually however, these are companies largely based on a variety of networks. In the case of the complex technology, a network includes a dozen of companies and different governmental agencies and organizations of the non-profit sector, such as universities. In addition, such a network, integrating various skills, must not be static. Innovative networks are continually evolving. Similarly, particular elements are still subject to common learning process. Often cited here as an example is Japan, where companies can effectively implement complex technologies. The factors of success that are mentioned here is the participation of the government in the innovation process - the support from his part and the specific culture which fosters cooperation, trust and building innovation on non-material knowledge (Wójnicka, 2008).

The new nature of the innovation process makes it necessary to adapt not only to its standards of measurement, but also the law (Wójnicka, 2008). For example, in the United 
States of America in the 1980s. the anti-monopolistic law was changed so as to enable the creation of consortia of research and development between companies. In a later period it appeared that companies must obtain a permit for a consortium, if it relates to companies from the same industry. In the European Community in 1985 there was introduced a block exclusion from the article 85 of the Treaty of Rome setting out the rules of competition law for certain categories of consortia of research and development.

The concept of the innovation system is a comprehensive way to view the innovation process. It draws attention both on the institutional aspects - the need to bring other institutions supporting the innovation process of companies, but especially on the relations between companies and those institutions, as well as between companies (Wójnicka, 2008). The interactions between companies and institutions shall mean their mutual openness and knowledge about the generated innovations, which will enable a more rapid diffusion of knowledge and innovation in the economy and social system to adapt more rapidly to technological change (Huges, Irfan, 2008).

Many studies point at the positive relationship between cooperation and innovation and competitiveness of businesses. In Canada on average $1 / 3$ of the industrial companies participates in the various agreements for cooperation. A greater percentage of cooperating companies is among large companies $-37.2 \%$ than the small and medium-sized companies $-28.3 \%$. At the same time, among large companies there are more innovative companies $(89.6 \%)$ than the average for the entire industrial sector is $(82.3 \%)$ (Wónicka, 2008). The cooperation is of crucial importance for an increase in creativity and innovation in the UK. From the research based on the internet survey conducted by the Confederation of British Industry (CBI) in the year 2000 it appears that $75 \%$ of 350 companies surveyed co-operated with other companies, researchers, consultants, research institutes or private research companies over the last 3 years (2000-2003) (Confederation of British Industry (CBI), 2001).

Companies and other innovation system actors can be linked in the innovation process in many ways. The basic traditional method are the transactional links based on the market. However, the increasingly frequent are non-market links, which are manifested in the cooperation agreements concerning joint research and development and innovation activity. The cooperation between the partners in the economic process and particularly the innovative one shows increasingly popular concepts of networks and clusters and innovation systems, among both researchers and politicians (Wojnicka, 2008).

Innovation systems are often clustered spatially - think of Sillicon Valley south of San Francisco (US) and Route 128 in the Boston area (also US) in the information and comunication technology sector. Regional clusters are mainly the product of innovation networks where private companies colaborate in R\&D endeavbours and join forces with universities and government laboaratories (Powe1l, Grodal, 2004, s. 57). The integration of companies in diverse networks is commonplace and enables the transfer of tacit knowledge. Tacit knowledge is usually not codified, and thus hard to obtain for 'outsiders' (Nonaka, Takeuchi, 1995). In networks, this knowledge travels through interpersonal exchange. Idea are shared, scrutinised, and discussed (Anheier, Fliegauf, 2013, s. 146).

An efficient innovation system introducing innovation and competitiveness of companies must have the proper linkages between science, industry and government. The 
scientific and technical policies of the countries moving towards the knowledge based economy favour the linkage between universities, industry and government. At the same time, the science sector should fall within the network of links with local, regional, national and foreign partners. As a result of such activity the boundaries between institutions shall disappear, and the entire system becomes more dynamic. The national policy can affect the science sector more than companies, so stronger links between science, industry and government can be inspired by the reform of the educational system.

The research into the innovations in companies have demonstrated that there is much more interaction and cooperation among the elements of the innovation system that occurs at the level of the region than the country. This results in the emphasis in recent years to research the potential and the regional innovation systems. In response to the need and assuming greater efficiency of the actions taken nearer to the entities, most regions that possess their own local authorities creates their own policy and proinnovation strategy. The reflection of the importance of the regional level for the innovation process are the European Union programs supporting the creation of regional innovation strategies - RIS, regional initiatives for the innovation and technology transfer - RITTS, and similar national programmes as e.g. InnoRegio in Germany (Economic Bulletin, 2002).

The latter point highights the political nature of the innovation process (Kim et al., 2007) that requires intra-organisational leadership as well as bargaining and persuasion across multiple levels. The complex nature of the innovation process often results in failurs where invention simply do not take off and remain nothing more than intriguing ideas. Ther invention make it, but their subsequent success varies widely (Anheier, Fliegauf, 2013, s. 140).

\subsection{Knowledge-based economy}

Typically, neoclassical economics neglected what was not contained in price information and made no effort to add to economic knowledge by trying to measure its economic contribution. Thereafter, Hayek $(1945,1948)$ identified the division of knowledge as the really central problem of economics as a social science and saw its key question how localized knowledge held by fragmentary firms and individuals nevertheless produces an ordered market demand and supply. The most significant fact about this system is the economy of knowledge with which it operates, or how little the individual participants need to know in order to be able to take the right action. In abbreviated form, by a kind of symbol, only the most essential information is passed on, and passed on only to those concerned (Hayek, 1948).

A further progenitor of the view that knowledge is a most important economic resource was Penrose (1959). She founded what has now evolved into the "dynamic capabilities of firms" approach to microeconomics (Teece, Pisano, 1996). She referenced the firm's characteristics as an administrative organization (Marshall, 1916; Coase, 1937) and home to accumulated human and material resources. The latter are inputs to services rendered, and these are the product of the firm's accumulated knowledge. 
A firm's rate of growth is limited by the growth of knowledge within it, but a firm's size by the extent of administrative efficiency (Penrose, 1995). In effect, in the words of Nonaka \& Takeuchi (1995) the firm is a repository of knowledge. Penrose (1995) also acknowledged that had the term been available in the $1950 \mathrm{~s}$, she would have referred to the dynamic capabilities of firms residing in knowledge networks (Quéré, 2003). Thus, Penrose (1995) noted the following crucial feature of the massively increased value of transferable knowledge to the wider economy for the firm. It must be empahasise that the rapid and intricate evolution of modern technology often makes it necessary for firms in related areas around the world to be closely in touch with developments in the research and innovation of firms in many centres (Penrose, 1995). Importantly, Penrose continues, the rise of business knowledge networks represents a metamorphosis in the contemporary economy. The key to the knowledge-based economy is at least partly revealed as this metamorphosis in the nature of industry organization to facilitate interaction with valuable knowledge, and not to conceal it, as was common in the previous phase of the global economy (Cooke, Leydesdorff, 2006).

Whereas the concept of a "knowledge economy" emerged within the context of the economic analysis of the quality of the input factors in the production process (Schumpeter, 1939), the term "knowledge-based economy" finds its roots in more recent discussions from a systems perspective (Sahal, 1981, 1985). National governments, for example, need a systems perspective for developing science, technology, and innovation policies (Nelson, 1982). By the second half of the 1950s, it had become increasingly clear to both policy makers and economic analysts that the continuing growth rates of Western economies could no longer be explained in terms of traditional economic factors such as land, labour, and capital. The "residue" (Abramowitz, 1956; OECD, 1964) had to be explained in terms of the upgrading of the labour force, surplus generated by interaction effects, and more generally the role of knowledge in the economy (Rosenberg, 1976). The Organization for Economic Co-operation and Development (OECD) was created in 1961 in order to organize and to coordinate science and technology policies among its member states, that is, the advanced industrial nations.

Studies of the knowledge-based economy focus not only on human capital, but also on the sectoral characteristics of the knowledge factor (Nelson, 1982; Pavitt, 1984). Technological trajectories and regimes shape innovation systems, but with a dynamics different from those of economic or geographical factors (Nelson, Winter, 1982). The recombination of the economic dynamics of the market, the dynamics of knowledge-based innovation, and governance generates the systems perspective. An innovation system can then be defined at the national level (Freeman, 1987, 1988; Lundvall, 1988, 1992; Nelson, 1993), at the regional level (Cooke, 1992; Cooke et al., 2004), or in terms of a dynamic model like the Triple Helix of university-industry-government relations (Etzkowitz, Leydesdorff, 2000; Leydesdorff, 1994).

The general argument about the salience of the organization of knowledge in the sectoral, skills, and spatial composition of the economy embraces the position of Castells (1996), who is widely known for the observation that productivity and competitiveness are, by and large, a function of knowledge generation and information processing, and that this has involved a Penrose-type metamorphosis entailing a different mode of thinking about economies. Thus the balance between knowledge and resources 
has shifted so far towards the former that knowledge has become by far the most important factor determining standards of living-more important than land, capital, or labour. Today's most advanced economies are fundamentally knowledge-based (Dunning, 2000). Even neoclassicists like Paul Romer recognize that technology (and the knowledge on which it is based) has to be viewed as an equivalent third factor along with capital and land in leading economies (Romer, 1990). Inevitably this leads to issues of the generation and exploitation of knowledge. (Whitley, 1984, 2001; Leydesdorff, 1995).

\subsection{Constructed advantage}

It has been suggested that the idea of absolut advantage in foreign trade originates with Adam Smith and developed by Ricardo and Torrens to comparative advantage and after was developed by Marshall and Ohlin. Foray \& Freeman (1993) re-introduced it yet scarcely explored it. More attention has been devoted to it in comparison to other well-known forms of economic advantage by De la Mothe \& Mallory (2003), as follows:

- Comparative Advantage - This idea, deriving from David Ricardo and foreign trade theory, explained economic welfare in terms of initial resource endowments traded between regions and nations. While policies were not excluded from such an analysis, they mainly added up to forms of mercantilism, and Ricardo advocated intervention regarding technological change. The overwhelming framework which government policy gave rise to and which promoted comparative advantage was laissez-faire (Cooke, Leydesdorff, 2006);

- Competitive Advantage - Thus countries with a large labour supply would naturally export goods that were labour-intensive (e.g., China), while countries that were technologically advantaged (e.g., the United States) produced and exported technologically advanced products. The paradox arose when advanced economies exported labour-intensive goods as well as technologically intensive goods. Krugman (1995) and Porter $(1990,1998)$ noted the competitive advantage of firms in which distributed supply chains and the role of large domestic markets became accepted (Cooke, Leydesdorff, 2006);

- Constructed Advantage - The "new competitive advantage" (Best, 2001) highlights regional development economics, the dynamic of which draws upon constructed advantage. This knowledge-based construction requires interfacing developments in various directions:

- Economy - regionalization of economic development; "open systems" inter-firm interactions; integration of knowledge generation and commercialization; smart infrastructures; strong local and global business networks (Desai, Vreeland, 2011);

- Governance - multi-level governance of associational and stakeholder interests; strong policy-support for innovators; enhanced budgets for research; vision-led policy leadership; global positioning of local assets;

- Knowledge Infrastructure - universities, public sector research, mediating agencies, professional consultancy, etc. have to be actively involved as structural puzzle-solving capacities; 
- Community and culture - cosmopolitanism; sustainability; talented human capital; creative cultural environments; social tolerance. This public factor provides a background for the dynamics in a Triple Helix of university-industry-government relations (Leydesdorff, Etzkowitz, 2003).

Early work on regional innovation systems (Cooke, 1992; Cooke, Morgan, 1994) attempted to capture the integrative and interactive nature of the knowledge-based economy examined from the regional perspective. The list of networking partners includes the base institutions like universities, research laboratories, research associations, industry associations, training agencies, technology transfer organizations (TTOs), specialist consultancies, government development, technology and innovation advisory agency programme-funding, and private investors. This knowledge exploration, examination and exploitation base supports the innovation efforts of large and small firms in many industries. Not all interactions are only intra-regional; many are also national and global, but in the most accomplished regional economies like Baden-Württemberg, a majority of such institutional networking interactions were regional, and on such regular terms that the networking had become systemic (Cooke, 2001).

\subsection{Triple Helix model constructed advantage}

It was Schumpeter who first recognized the importance of knowledge in the economy by his reference to "new combinations of knowledge" at the heart of innovation and entrepreneurship (Schumpeter, 1911). Studies of the knowledge-based economy focus not only on human capital, but also on the sectoral characteristics of the knowledge factor (Nelson, 1982; Pavitt, 1984; Dunning, 2000). An innovation system can be defined at the national level (Freeman, 1987, 1988; Lundvall, 1988, 1992; Nelson, 1993), at the regional level (Cooke, 1992; Cooke et al., 2004), or in terms of a dynamic model like the Triple Helix of university-industry-government relations (Etzkowitz, Leydesdorff, 2000; Leydesdorff, 1994).

In the Triple Helix model constructed advantages have been conceptualized as the surplus value of an overlay of relations among the three components of a knowledge-based economy: (1) the knowledge-producing sector (science), (2) the market, and (3) governments. Those places with research universities witness a growing demand for knowledge transfer to industry and, through government, to society (Etzkowitz, Leydesdorff, 1998; Etzkowitz et al., 2000). Moreover, the spread of universities is reasonably uniform in advanced industrial countries. For research knowledge, industry and government can be expected to pay more for privileged access to knowledge-based growth opportunities by funding research, stimulating closer interactions among the three institutional partners, subsidizing infrastructure (e.g., incubators and science parks), and stimulating academic entrepreneurship skills and funding (Cooke, Leydesdorff, 2006).

The effect of the growth in importance of regional (and other) innovation systems is to pervade the regional and other economies with scientific, synthetic and symbolic knowledge to a greater extent than ever before. R\&D management and S\&T policies at 
relevant government levels enlarge the set of options. These, however, are not fixed but evolving distributions in which some regions are more developed as knowledge-based economies than others. Hence, the post-1970s fascination with "high-tech" regions worldwide. Today, however, as the Triple Helix perspective suggests, with universities and their related research laboratories spread throughout most regions, many more economies have the chance to access not only yesterday's "global" knowledge announced on the Internet and exploitable by all, but local knowledge of potentially high value generated from research conducted in relation to regional capabilities. Thus, as the knowledge base becomes pervasive, the knowledge economy is further reinforced. The knowledge base of an economy can be considered as a second-order interaction effect among Triple Helix interfaces between institutions and functions in different spheres. Proximity enhances the chances for couplings and, therefore, the formation of technological trajectories. In this manner, connections between regional innovation systems and markets (an understudied aspect in the broad field of innovation studies) may be facilitated (Cooke, Leydesdorff, 2006).

\subsection{Europe 2020 strategy and innovation Union}

The budgetary and economic policies with the Stability and Growth Pact and the Europe 2020 strategy are the basis for building a common understanding about the priorities for action at the national and EU level as the EU seeks to return to a path of sustainable growth and job creation. It must be emphasized that the EU economy is slowly starting to emerge from the deepest financial and economic crisis in decades. The Commission recommends focusing on the same five priorities that were identified in last year's Survey:

- Pursuing differentiated, growth-friendly fiscal consolidation;

- Restoring normal lending to the economy;

- Promoting growth and competitiveness for today and tomorrow;

- Tackling unemployment and the social consequences of the crisis;

- Modernising public administration.

The key driver of the problems is Europe's structural innovation gap: compared to its competitors, Europe's patenting performance is weak and it lags behind in developing new products, new processes and new services. To boost productivity and growth, it is critically important to generate breakthrough technologies and translate them into new products, processes and services. Europe has taken an early technological lead in many key technology areas, but in the face of growing competition its advantage is tenuous, and has not translated into an innovative and competitive lead. A timely and targeted European policy is needed for bridging the "valley of death" if Europe is to remain competitive (SEC 1428 final 201).

This key driver is underpinned by the following structural problem drivers:

- Insufficient contribution of research and innovation to tackling societal challenges;

- Insufficient technological leadership and innovation capability of firms;

- The need to strengthen the science base;

- Insufficient cross-border coordination. 
The Innovation Union plan contains over thirty actions points, with the aim to do three things:

- make Europe into a world-class science performer;

- remove obstacles to innovation - like expensive patenting, market fragmentation, slow standard-setting and skills shortages - which currently prevent ideas getting quickly to market; and

- revolutionise the way public and private sectors work together, notably through Innovation Partnerships between the European institutions, national and regional authorities and business.

Innovation Union is the European Union strategy to create an innovation-friendly environment that makes it easier for great ideas to be turned into products and services that will bring economy growth and jobs (Figure 1, Figure 2). The Annual Growth Survey for 2013 launches the 2013.

Figure 1. GDP trends in the EU: levels and rates

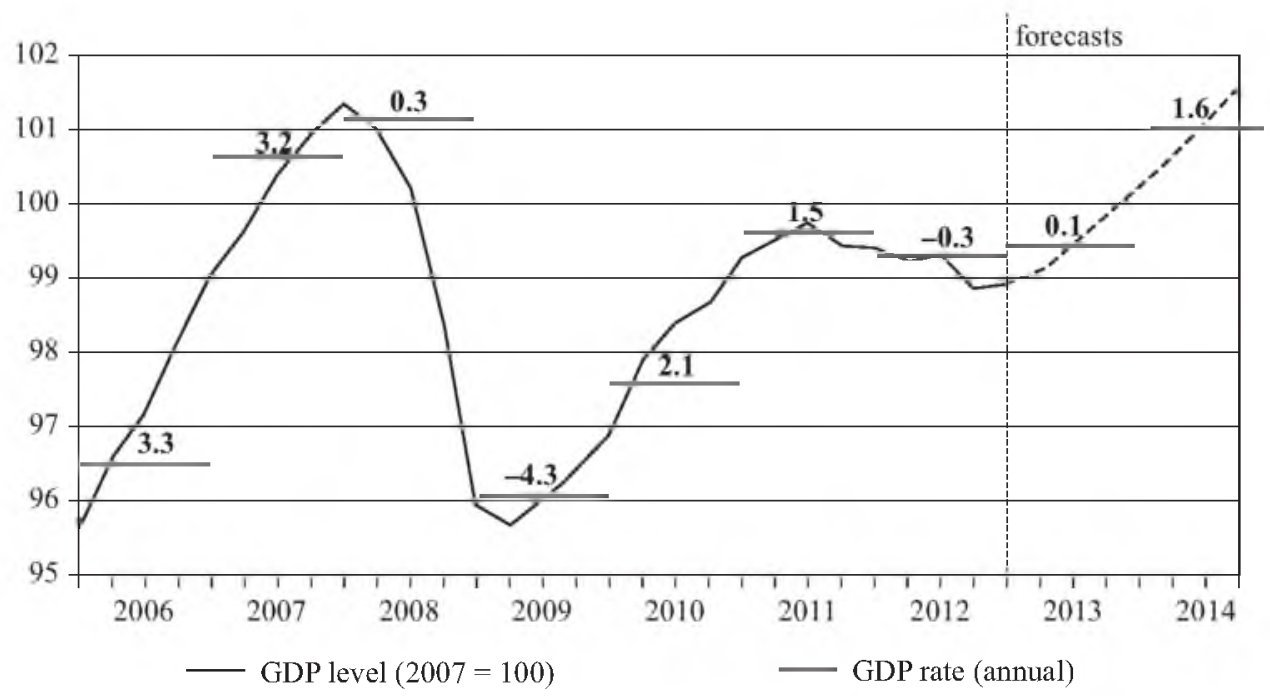

Source: Growth, competitiveness and jobs priorities for the European Semester 2013 (2013), Presentation of J. M. Barroso, President of the European Commission to the European Council of 14-15 March 2013, http://ec.europa.eu/news/pdf/sg.2013-00286-01-04-eu.tra-00.pdf, 24.01.2014.

European semester for economic policy coordination, which ensures Member States align their budgetary and economic policies with the Stability and Growth Pact and the Europe 2020 strategy. It is the basis for building a common understanding about the priorities for action at the national and EU level as the EU seeks to return to a path of sustainable growth and job creation.

The Annual Growth Survey should feed into national economic and budgetary decisions, which Member States will set out in Stability and Convergence Programmes (under the Stability and Growth Pact) and National Reform Programmes (under the Europe 2020 strategy) in April 2013. These programmes will form the basis for the European Commission's proposals for country-specific recommendations in May 2013. 
Figure 2. Number of people employed in the EU (in million)

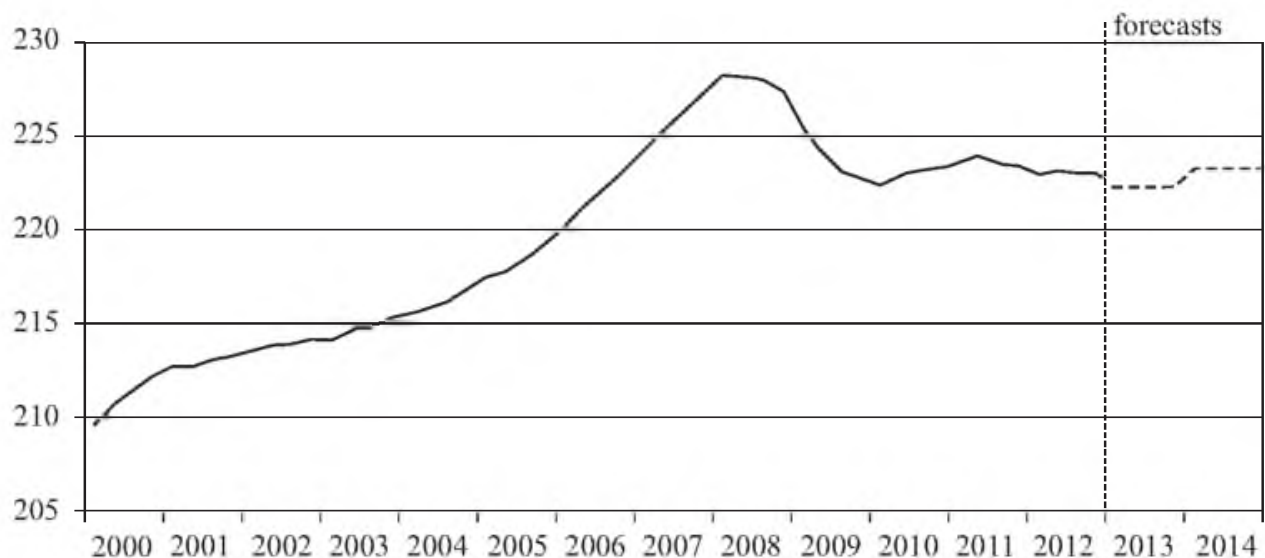

Source: Growth, competitiveness and jobs priorities for the European Semester 2013 (2013), Presentation of J. M. Barroso, President of the European Commission to the European Council of 14-15 March 2013, http://ec.europa.eu/news/pdf/sg.2013-00286-01-04-eu.tra-00.pdf, 24.01.2014.

It must be emphasized that the EU economy is slowly starting to emerge from the deepest financial and economic crisis in decades. However, although important action has already bee taken and positive trends are beginning to emerge, to remain some dis-

\section{Global competitiveness index 2012-2013}

\begin{tabular}{|c|l|}
\hline Rank & \multicolumn{1}{|c|}{ Country } \\
\hline 1 & Switzerland \\
\hline 2 & Singapore \\
\hline 3 & Finland \\
\hline 4 & Sweden \\
\hline 5 & Netherlands \\
\hline 6 & Germany \\
\hline 7 & United States \\
\hline 8 & United Kingdom \\
\hline 9 & Hong Kong SAR \\
\hline 10 & Japan \\
\hline 12 & Denmark \\
\hline 16 & Austria \\
\hline 17 & Belgium \\
\hline 21 & France \\
\hline 22 & Luxembourg \\
\hline 27 & Ireland \\
\hline 34 & Estonia \\
\hline & \\
\hline
\end{tabular}

\begin{tabular}{|c|l||}
\hline \hline Rank & \multicolumn{2}{|c|}{ Country } \\
\hline 36 & Spain \\
\hline 39 & Czech Republic \\
\hline 41 & Poland \\
\hline 42 & Italy \\
\hline 45 & Lithuania \\
\hline 47 & Malta \\
\hline 49 & Portugal \\
\hline 55 & Latvia \\
\hline 56 & Slovenia \\
\hline 58 & Cyprus \\
\hline 60 & Hungary \\
\hline 62 & Bulgaria \\
\hline 71 & Slovak Republic \\
\hline 78 & Romania \\
\hline 81 & Croatia \\
\hline 96 & Greece \\
\hline
\end{tabular}

Source: Growth, competitiveness and jobs priorities for the European Semester 2013 (2013), Presentation of J. M. Barroso, President of the European Commission to the European Council of 14-15 March 2013, http://ec.europa.eu/news/pdf/sg.2013-00286-01-04-eu.tra-00.pdf, 24.01.2014. 
tance from a recovery (Table 1). To restore confidence and return to growth, it is essential that Member States maintain the reform momentum, and for this reason the Commission recommends focusing on the same five priorities that were identified in last year's Survey (Figure 3):

- Pursuing differentiated, growth-friendly fiscal consolidation;

- Restoring normal lending to the economy;

- Promoting growth and competitiveness for today and tomorrow (Table 1, Figure 3);

- Tackling unemployment and the social consequences of the crisis;

- Modernising public administration.

Figure 3. Productivity levels and trends 2000-2012

(hourly productivity levels in Euro per hour worked)

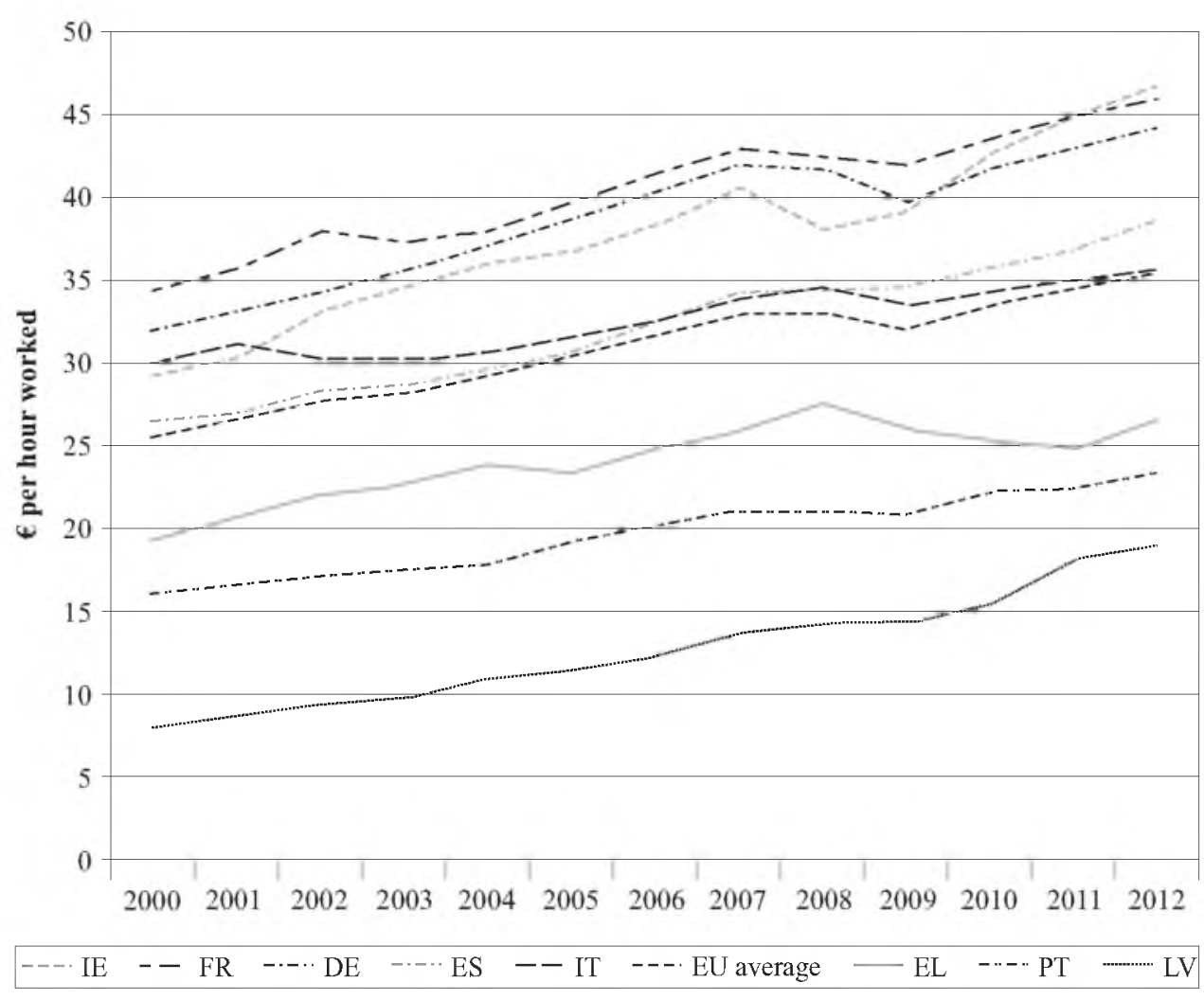

Source: Growth, competitiveness and jobs priorities for the European Semester 2013 (2013), Presentation of J. M. Barroso, President of the European Commission to the European Council of 14-15 March 2013, http://ec.europa.eu/news/pdf/sg.2013-00286-01-04-eu.tra-00.pdf, 24.01.2014.

The deleveraging and adjustment process is inevitable and the main task of policy makers is to manage it and alleviate the associated economic and social consequences. Fiscal adjustment has to continue along the path of a differentiated growth-friendly consolidation strategy in view of the high debt levels and long-term challenges to public finances. 


\subsection{Financial instrument Horizon 2020}

From 2014 to 2020 with a budget of just over $€ 70$ billion, the EU's new programme for research and innovation is part of the drive to create new growth and jobs in Europe.

Figure 4. R\&D investments in the EU as a \% of GDP

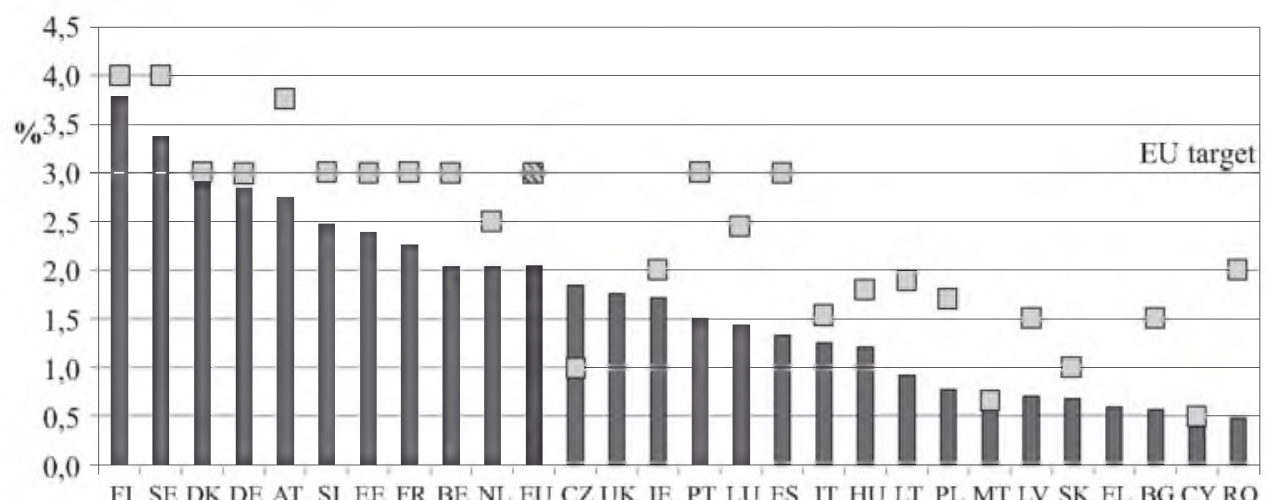

2011 performance* $\quad \square 2020$ national target** $^{*}$

* EL: 2007.

*** No targets set by EL and the UK. For CZ: a target (of 1\%) is available only for the public sector. For IE: the target is $2.5 \%$ of GNP which is eistimated to be equivalent to $2.0 \%$ of GDP. For LU: the target is between $2.30 \%$ and $2.60 \%(2.45 \%$ was assumed $)$.

Source: Growth, competitiveness and jobs priorities for the European Semester 2013 (2013), Presentation of J. M. Barroso, President of the European Commission to the European Council of 14-15 March 2013, http://ec.europa.eu/news/pdf/sg.2013-00286-01-04-eu.tra-00.pdf, 24.01.2014.

The proposed support for research and innovation under Horizon 2020 will:

- Strengthen the EU's position in science with a dedicated budget of $€ 24,341$ million. This will provide a boost to top-level research in Europe, including the very successful European Research Council (ERC);

- Strengthen industrial leadership in innovation $€ 17,015$ million. This includes major investment in key technologies, greater access to capital and support for SMEs;

- Provide $€ 30,956$ million to help address major concerns shared by all Europeans such as climate change, developing sustainable transport and mobility, making renewable energy more affordable, ensuring food safety and security, or coping with the challenge of an ageing population.

It must be emphasized that Horizon 2020 will tackle societal challenges by helping to bridge the gap between research and the market by, for example, helping innovative enterprise to develop their technological breakthroughs into viable products with real commercial potential. This market-driven approach will include creating partnerships with the private sector and Member States to bring together the resources needed.

International cooperation (Fukuda-Parr, 2011; Wibbels, Ahlquist, 2011) will be an important cross-cutting priority of Horizon 2020. In addition to Horizon 2020 being fully open to international participation, targeted actions with key partner countries and 
regions will focus on the EU's strategic priorities. Through a new strategy, a strategic and coherent approach to international cooperation will be ensured across Horizon 2020. Horizon 2020 will be complemented by further measures to complete and further develop the European Research Area by 2014. These measures will aim at breaking down barriers to create a genuine single market for knowledge, research and innovation.

It must be emphasized that new browth strategy of the EU need for public intervention, subsidiarity and European Added Value. There is a clear case for public intervention to tackle the problems above. Markets alone will not deliver European leadership. Large-scale public intervention through both supply and demand measures will be needed to overcome the market failures associated with systemic shifts in basic technologies. However, Member States acting alone will not be able to make the required public intervention. Their investment in research and innovation is comparatively low, is fragmented and suffers from inefficiencies - a crucial obstacle when it comes to technological paradigm shifts. It is difficult for Member States on their own to accelerate technology development over a sufficiently broad portfolio of technologies, or to tackle the lack of transnational coordination.

As highlighted in the proposal for the next Multi-annual Financial Framework, the EU is well positioned to provide added value, through measures to coordinate national funding, which restructure more efficiently the European research and innovation landscape, and through implementing collaborative research and mobility actions, which generated critical mass (SEC 1428 final 2011).

A next generation programme should build on the experience from past Framework Programmes for Research and Technological Demonstration (FP), the Competitiveness and Innovation Programme (CIP), and the European Institute of Technology and Innovation (EIT) It is important to underline that over several decades, EU programmes have funded Europe's best researchers and institutes, and produced large-scale structur-

Figure 5. Share of young people (age 30-34) with tertiary attainment

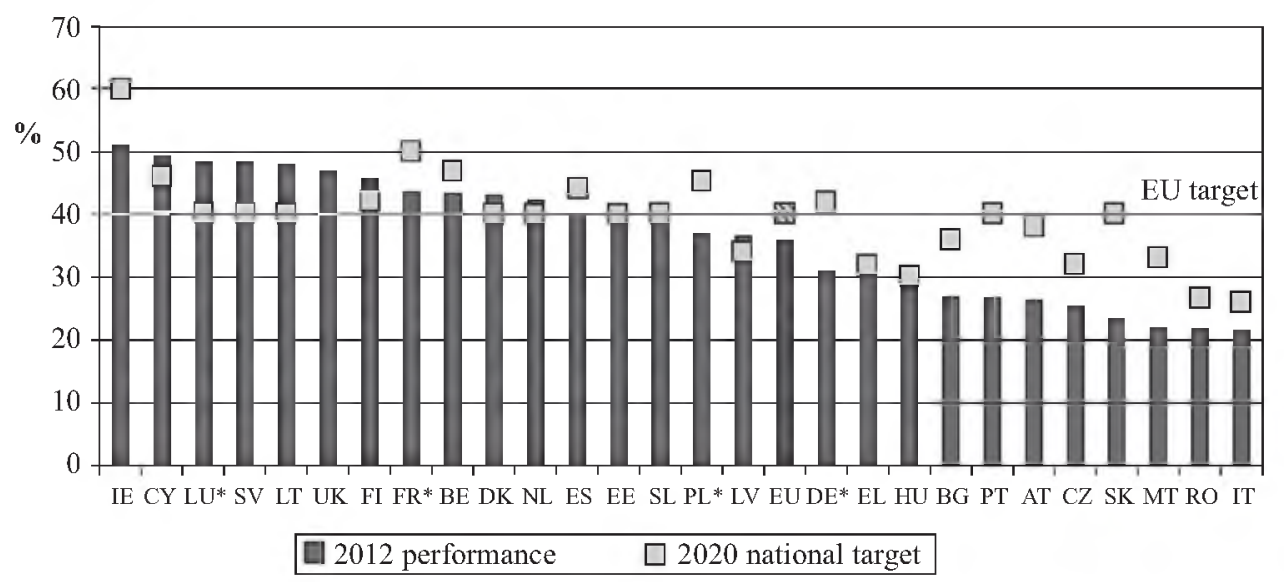

Source: Growth, competitiveness and jobs priorities for the European Semester 2013 (2013), Presentation of J. M. Barroso, President of the European Commission to the European Council of 14-15 March 2013, http://ec.europa.eu/news/pdf/sg.2013-00286-01-04-eu.tra-00.pdf, 24.01.2014. 
ing effects, scientific, technological and innovation impacts, micro-economic benefits, and downstream macro-economic, social and environmental impacts for all EU Member States. However, important lessons can be learned from the past, including academic insights and stakeholder feedback. Research, innovation and education (Figure 5) should be addressed in a more coordinated manner and research results better disseminated and valorised into new products, processes and services. Especially education and skills are key for increasing of innovation levels (Figure 5, Figure 6) and creat new job (Figure 6, Table 2). The intervention logic should be more focused, concrete, de-

Figure 6. Digital jobs: vacancies and graduates (numbers)

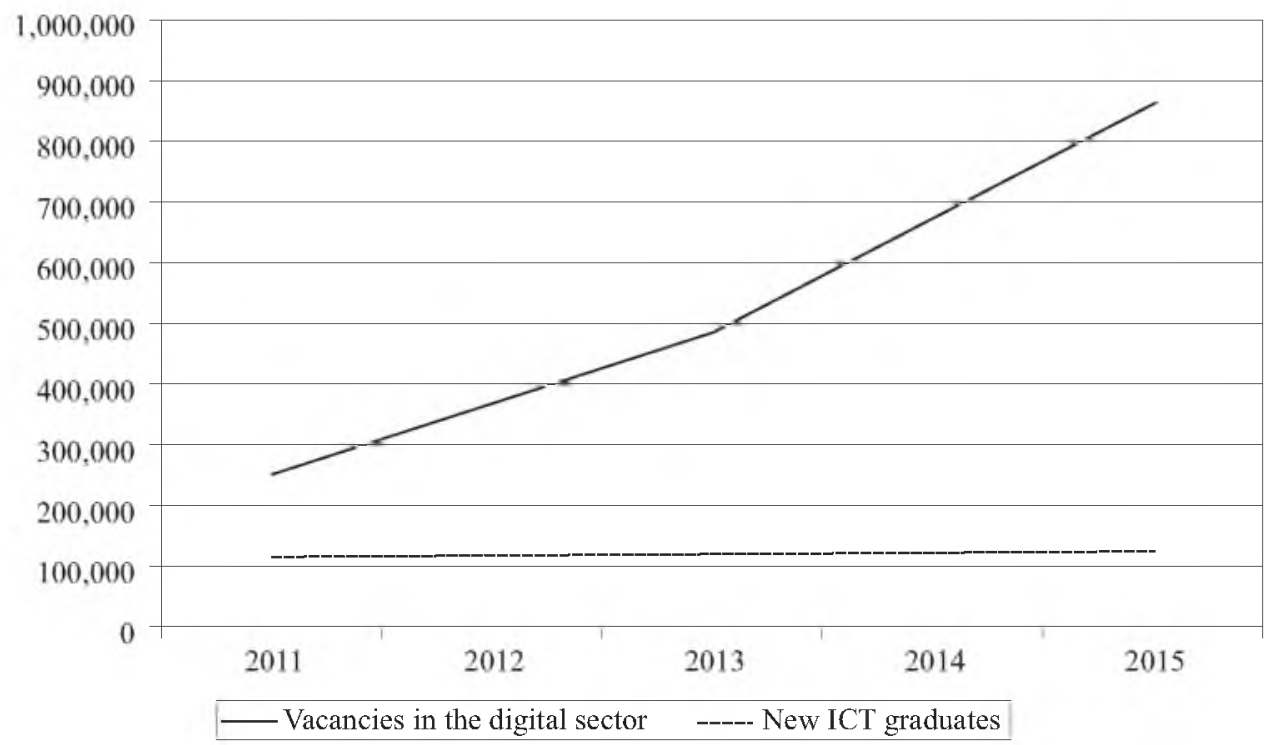

Source: Growth, competitiveness and jobs priorities for the European Semester 2013 (2013), Presentation of J. M. Barroso, President of the European Commission to the European Council of 14-15 March 2013, http://ec.europa.eu/news/pdf/sg.2013-00286-01-04-eu.tra-00.pdf, 24.01.2014.

tailed and transparent. Programme access should be improved and participation increased from start-ups, SMEs, industry, less performing Member States and extra-EU countries (SEC 1428 final 2011).

Unemployment rate and numbers of unemployed, overall and among young people (under 25)

(December 2012)

\begin{tabular}{|c|c|c|c|c|}
\hline & $\begin{array}{c}\text { Unemployment rates } \\
\text { in \% (total population) }\end{array}$ & $\begin{array}{c}\text { Number of persons } \\
\text { unemployed (rounded) }\end{array}$ & $\begin{array}{c}\text { Youth unemployment } \\
\text { rates in \% }\end{array}$ & $\begin{array}{c}\text { Number of young } \\
\text { unemployment (rounded) }\end{array}$ \\
\hline 1 & 2 & 3 & 4 & 5 \\
\hline $\mathrm{EU}$ & 10.7 & $25,926,000$ & 23.4 & $5,702,000$ \\
\hline $\mathrm{BE}$ & 7.5 & 368,000 & 20.0 & 85,000 \\
\hline $\mathrm{BG}$ & 12.3 & 411,000 & 27.5 & 69,000 \\
\hline $\mathrm{CZ}$ & 7.5 & 394,000 & 21.0 & 78,000 \\
\hline
\end{tabular}




\begin{tabular}{|c|c|c|c|c|}
\hline 1 & 2 & 3 & 4 & 5 \\
\hline DK & 8.0 & 233,000 & 14.7 & 65,000 \\
\hline $\mathrm{DE}$ & 5.3 & $2,236,000$ & 8.0 & 362,000 \\
\hline $\mathrm{EE}$ & 9.9 & 68,000 & 19.5 & 13,000 \\
\hline $\mathrm{IE}$ & 14.7 & 316,000 & 30.2 & 68,000 \\
\hline $\mathrm{EL}$ & 26.8 & $1,346,000$ & 57.6 & 181,000 \\
\hline ES & 26.1 & $5,972,000$ & 55.6 & 957,000 \\
\hline FR & 10.6 & $3,123,000$ & 27.0 & 794,000 \\
\hline IT & 11.2 & $2,875,000$ & 36.6 & 610,000 \\
\hline $\mathrm{CY}$ & 14.7 & 66,000 & 28.5 & 12,000 \\
\hline LV & 14.1 & 146,000 & 31.7 & 32,000 \\
\hline LT & 12.3 & 187,000 & 23.6 & 31,000 \\
\hline $\mathrm{LU}$ & 5.3 & 13,000 & 18.8 & 3,000 \\
\hline $\mathrm{HU}$ & 10.9 & 476,000 & 27.9 & 87,000 \\
\hline MT & 6.7 & 13,000 & 15.7 & 5,000 \\
\hline NL & 5.8 & 520,000 & 10.0 & 144,000 \\
\hline AT & 4.3 & 188,000 & 8.5 & 51,000 \\
\hline $\mathrm{PL}$ & 10.6 & $1,845,000$ & 28.4 & 436,000 \\
\hline PT & 16.5 & 897,000 & 38.3 & 174,000 \\
\hline RO & 6.5 & 661,000 & 23.0 & 194,000 \\
\hline SI & 10.0 & 102,000 & 26.9 & 22,000 \\
\hline SK & 14.7 & 405,000 & 35.9 & 85,000 \\
\hline FI & 7.7 & 206,000 & 18.9 & 63,000 \\
\hline SE & 7.8 & 395,000 & 23.9 & 154,000 \\
\hline UK & 7.8 & $2,474,000$ & 20.5 & 938,000 \\
\hline
\end{tabular}

Source: Growth, competitiveness and jobs priorities for the European Semester 2013 (2013), Presentation of J. M. Barroso, President of the European Commission to the European Council of 14-15 March 2013, http://ec.europa.eu/news/pdf/sg.2013-00286-01-04-eu.tra-00.pdf, 24.01.2014.

Monitoring and evaluation need to be strengthened. In order to tackle the problems identified above, the following objectives have been set. The general objective of the next EU spending programme for research and innovation will be to contribute to the objectives of the Europe 2020 strategy and to the completion of the European Research Area.

In order to achieve this general objective, there are five specific objectives:

- Strengthen Europe's science base by improving its performance in frontier research, stimulating future and emerging technologies, encouraging cross-border training and career development, and supporting research infrastructures;

- Boost Europe's industrial leadership and competitiveness through stimulating leadership in enabling and industrial technologies, improving access to risk finance, and stimulating innovation in SMEs;

- Increase the contribution of research and innovation to the resolution of key societal challenges;

- Provide customer-driven scientific and technical support to Union policies;

- Help to better integrate the knowledge triangle - research, researcher training and innovation. 
The options considered were designed and evaluated in relation to stakeholders' views, the problems and the objectives above. They take into account some key parameters set out in the EU budget review: the need to focus on instruments with proven European added value, to develop a more results-driven approach, to leverage other public and private funding, and to design EU instruments that work together in a single strategic framework.

This Impact Assessment considers four policy options:

- Business-as-usual (BAU): maintaining the current plurality of programmes for R\&D and innovation (Figure 4): In this scenario, the three main existing EU sources of funding for research and innovation - FP7, the innovation-related part of the CIP, and the EIT - are simply carried forward into the next multiannual financial framework as separate instruments, and in their current formats.

- Improved business-as-usual: loose integration and stand-alone simplification (BAU+): In this scenario, FP7, the innovation-related part of the CIP, and the EIT remain separate instruments and retain their current formats but are put together under a "common roof'; loose coordination mechanisms are established between them. The implementing modalities of each programme are simplified separately, but no single set of simplified rules, funding schemes, support services etc. applies across the three programmes.

- Horizon 2020 - Establishing a single strategic framework for Research and Innovation: In this scenario, FP7, the innovation-related part of the CIP, and the EIT are fully integrated into a single unitary framework: Horizon 2020, The Framework Programme for Research and Innovation. The current separation between research and innovation activities is eliminated. Horizon 2020 sets out three strategic policy objectives: raising and spreading the levels of excellence in the research base; tackling major societal challenges; and maximising competitiveness impacts of research and innovation. Horizon 2020 is structured around three priorities which link directly to these aims. The selection of actions and instruments is driven by policy objectives and not by instruments. Horizon 2020 also integrates a major simplification and standardisation of funding schemes and implementing modalities across all areas.

- Bring to an end EU level R\&D financing and re-nationalise R\&D and innovation policies: The renationalisation option consists of discontinuing EU research and innovation programmes and of spending those funds at Member State level. A discontinuation option, which is assessed to a lesser extent, consists of discontinuing EU research and innovation programmes and not spending those funds at Member State level (SEC 1428 final 2011).

Interseting is to indicated how the options were compared. The four policy options were compared along a range of key parameters relevant to assessing public intervention in research and innovation:

- clarity of focus of the intervention;

- quality of the intervention logic;

- extent to which the intervention achieves critical mass at both programme and project level;

- extent of flexibility associated with the intervention; 
- extent to which it promotes excellence;

- accessibility and reach:

- degree of stakeholder support:

- impact on SMEs:

- extent to which the intervention promotes knowledge triangle and broader horizontal policy coordination:

- impacts of the intervention - structuring, leverage, innovation, economic and competitiveness, social, environmental, and EU policy impacts;

- cost-effectiveness.

The comparison along these parameters was done using a range of evidence including: ex post evaluations; foresight studies; analyses of FP and Community Innovation Survey data; science, technology and innovation indicators; econometric modelling; reviews of academic literature; competitiveness studies; expert hearings etc.

Horizon 2020 also maximises cost-effectiveness. On the cost side, its farreaching integration, simplification and harmonisation will reduce costs for the Commission and for applicants. At the same time, the Horizon 2020 option maximises the benefits through a close integration of research, innovation and training. This will provide the best approach for ensuring that investments made at EU level in research projects are fully valorised into patents and new products, processes and services.

\section{Box 1. Quantifying economic, competitiveness and social impacts}

The enhanced scientific, technological and innovation impacts produced by Horizon 2020 should translate into larger downstream economic and competitiveness impacts. It is estimated that by 2030 it could generate the following impacts over and above the BAU option:

- Horizon 2020 will stimulate Europe's economic growth, generating 0.53 percent of extra GDP.

- It will also enhance Europe's competitiveness, increasing its exports by 0.79 percent, and reducing its imports by 0.1 percent.

- It will create jobs for Europe's citizens, increasing employment by 0.21 percent.

Under the renationalisation and discontinuation options, the effects would be weaker compared with the BAU option by 2030 :

- Renationalisation would reduce GDP by 0.04 percent, cnt 0.06 pereent off exports, have no effect for imports, but would lead to a job loss of 0.01 percent.

- Discontinuation would shave 0.39 percent off GDP, decrease exports by 0.58 percent, and raise imports by 0.05 percent, while producing job losses of 0.19 percent.

Comparing the positive effects of the Horizon 2020 option with the negative effects of the discontinuation option demonstrates its true added value:

- By 2030, it is expected to generate an extra 0.92 percent $(0.53-0.39)$ of GDP, 1.37 percent $(0.79-0.58)$ of exports, -0.15 percent $(0.10-0.05)$ of imports, and $0.40(0.21-0.19)$ percent of employment.

Source: (SEC 1428 final 2011).

The BAU+ option would allow for some alignment of objectives and achieve a certain degree of simplification producing positive effects on administrative burden, accessibility, reach, structuring effects, leverage effects, innovation impacts and downstream economic, social, environmental and EU policy impacts. In the case of the renationalisation option, it would be more difficult to orient Europe's research and innovation programmes on commonly agreed objectives while critical mass and excellence would be compromised. The quality of the intervention logic, the level of flexibility, accessibility and reach, and the extent of knowledge triangle and broader 
horizontal policy coordination could in theory be enhanced more easily at national or regional level (Acharya, 2011) though this is not the case now and would involve important trade-offs (Wibbels, Ahlquist, 2011). This would compromise the return on investment in research as scientific, technological and innovation impacts would be reduced, which would translate into smaller economic and competitiveness, social, environmental and EU policy impacts. A summary of the comparison of options is given in the table 3.

Table 3

Impacts of the BAU+, Horizon 2020, and renationalisation options compared to the BAU option

\begin{tabular}{|c|c|c|c|}
\hline Dimension & BAU+ & Horizon 2020 & Renatioalisation \\
\hline \multicolumn{4}{|c|}{ Effectiveness } \\
\hline Focus & + & ++ & $+(1)$ \\
\hline Intervention logic & $=$ & + & $+/-(2)$ \\
\hline Accessibility, reach & + & ++ & $++(4)$ \\
\hline SMEs & + & ++ & $++(5)$ \\
\hline Excellence & $=$ & + & - \\
\hline Critical mass & $=$ & $=$ & - \\
\hline Structuring effect & + & ++ & - \\
\hline Leverage effect & + & ++ & - \\
\hline Innovation impact & + & ++ & - \\
\hline Economic and competitiveness impact & + & ++ & - \\
\hline Social impact & + & ++ & - \\
\hline Environmental impact & + & ++ & - \\
\hline Impact on EU policy & + & ++ & - \\
\hline \multicolumn{4}{|c|}{ Efficiency } \\
\hline Reduction of administrative costs & + & ++ & $++(3)$ \\
\hline Reduction of participation costs & + & ++ & $++(3)$ \\
\hline \multicolumn{4}{|c|}{ Coherence } \\
\hline Knowledge triangle coordination & + & ++ & $+/-(2)$ \\
\hline Broader horizontal policy coordination & $=$ & + & $+1-(2)$ \\
\hline Flexibility & $=$ & + & $++(3)$ \\
\hline
\end{tabular}

Notes: (1) Easier to focus programmes, but more difficult to focus them on pan-European objectives; (2) In theory, easier to achieve/enhance; in practice, mixed Member State and regional performance; (3) but reduced critical mass, excellence; (4) but reduced critical mass and ability to pool resources; (5) but reduced access to foreign partners, capabilities, markets.

Source: (SEC 1428 final 2011).

Under Horizon 2020, only those kinds of activities will be supported that have passed the European added value test. Under the proposal on the next MFF, the funding for Horizon 2020 amounts to $€ 80$ billion (constant 2011 prices), which represents a 46 percent increase with respect to comparable funding under the MFF 2007-2013 (constant 2011 prices). The new system for the evaluation and monitoring of Horizon 2020 will be based on a comprehensive, well-timed and harmonised strategy, with a strong focus on throughput, output, results and impacts (SEC 1428 final 2011). 


\section{Results}

What indicates the importance and innovativeness of the research is the presentation of the region, innovation and knowledge in the strategy of the European Union economic growth and social security. According to the new theory of growth being the best theoretical foundation for the concept of the innovation system, the primary factor influencing the economic growth is the endogenous technical progress. In the endogenous theories workers are seen as an element capable of active interaction and creating changes in the production process, and therefore a huge role in increasing productivity is ascribed to human capital and knowledge. The organization of pure and applied knowledge can increasingly pervade the economy when scientific and technological knowledge is institutionally produced and systematically controlled.

Stronger links between science and industry are forced by the changing nature of technology, which is a complex and systemic. That makes it necessary for companies to be able to solve complex problems with a greater number of variables. This leads to creation of knowledge in companies, which is not only specific, but depends on the development of complementary and sometimes basic scientific fields. In response to such needs of companies, there have been a variety of knowledge disciplines founded, including the theory, methodology and methods of measurement, useful in solving complex problems. Companies are becoming increasingly multi-technological and incorporate multiple disciplines in their problem solving mechanism. The movement of patents, citations or product development in a knowledge-based industries complements both research and commercial activities. The links between science and industry can therefore be measured, among other things, through the so-called knowledge-absorption (dependence on the science) of particular industries, related to the given technology or technological system.

The research into the innovations in companies demonstrate that there is much more interaction and cooperation among the elements of the innovation system that occurs at the level of the region than the country. This results in the emphasise in recent years to research the potential and the regional innovation systems. In response to the need and assuming greater efficiency of the actions taken nearer to the entities, most regions that possess their own local authorities creates their own policy and proinnovation strategy. The Triple Helix challenge is picked up also in an attempt to identify the factors that affect the ability of universities both to create new knowledge and to deploy that knowledge in economically useful ways and thereby contribute to economic growth and prosperity. It seems therefore that constructed advantage based on regional innovation systems that transceive over long distances as well as through regional networks is becoming the model of choice for achieving accomplished regional economic development.

International cooperation is an important cross-cutting priority of Horizon 2020 . In addition to Horizon 2020 being fully open to international participation, targeted actions with key partner countries and regions will focus on the EU's strategic priorities. Through a new strategy, a strategic and coherent approach to international cooperation is ensure across Horizon 2020.

Horizon 2020 maximises cost-effectiveness. On the cost side, its farreaching integration, simplification and harmonisation reduce costs for the Commission and for ap- 
plicants. At the same time, the Horizon 2020 option maximises the benefits through a close integration of research, innovation and training. This provide the best approach for ensuring that investments made at EU level. Structural reforms, which improve competitiveness, wage responsiveness and price flexibility are key to improving adjustment capabilities and to stimulating the transfer of resources from declining to growing sectors.

Priority must be measures which support economic development and employment. It is necessary to pursue in connection with this proactive and a cross-cutting strategy. The aim is to put an end to the market fragmentation, remove the obstacles and barriers hampering the movement of services, innovation and creativity. These actions should reinforce a uniform internal market the EU and outwards to enhance the competitiveness of the global primarily in relation to the USA and Japan as well as emerging markets such as Brazil, Russia, India and China (BRIC). This should be done mainly by an increase in the financial outlay on research and development (R\&D) and the development of new knowledge-based economy.

Higher education can be used for accelerating the economic development and for building the political democracy. A special importance of the higher education is seen in a long-term education of societies and also in a permanent education, which is related to the requirements resulting from fast technical and technological changes, and especially to the growing role of computer technology, used in a very important segment of economic and social development processes, that is, in information processes. At the same time the value of higher education in the whole education system will be growing. As a result, the ties between higher education, scientific research and production processes, that is, the ties characteristic for knowledge-based society, will help to reduce unemployment. There is also the need for steady modernisation of teaching curricula in existing university specialisations. This should be complemented by a broad international cooperation, especially with the best scientific and academic centres.

\section{Conclusion}

It must be emphasized that structural reforms are necessary to facilitate adjustment and improve the framework conditions for European Union economic growth and social security. Reforms promoting job creation, investment in innovation, skills and inclusive growth are necessary to tackle the risk of hysteresis and alleviate the negative impact of the crisis on social conditions. A fair distribution of the adjustment burden across society is important for sustained growth. Ultimately, however, a coherent policy mix encompassing both macro-financial and structural policies is indispensable for growth to resume. Hence a determined policy action on all these fronts is necessary to counter the negative dynamics and improve the economic situation in a sustainable manner.

The important of the research is the conclusion that there is positive dependence between innovation activity in innovation system and effectiveness of the innovation process. The more interaction and cooperation it can observe on the regional level than on the state. The new programme of the scientific and innovation research Europe 2020 
and Innovation Union are very important factors in the strategy of the European Union economic growth end social security.

\section{Bibliography}

Abramowitz M. (1956), Resource and Output Trends in the United States since 1870, "American Economic Review", no 46, p. 5-23.

Acharya A. (2011), Norm Subsidiarity and Regional Orders: Sevreignty, Regionalismn, and Rule-Making in the Third World, "International Studies Quarterly Journal of the International Studies Association", vol. 55, no 1, March.

Anheier H. K., Fliegauf M. T. (2013), The Contribution of Innovation Research to Undrestanding Governance Innovation: A review, in: H. K. Anheier, Governance Challenges and Innovations: Financial and Fiscal Governance, Oxford University Press, Oxford.

Best M. (2001), The New Competitive Advantage, Oxford University Press, Oxford.

Burton-Jones A. (1999), Knowledge Capitalism, Oxford University Press, Oxford.

Castells M. (1996), The Rise of the Network Society, Blackwell, Oxford.

Coase R. (1937), The nature of the firm, "Economica", no 4, p. 386-405.

Confederation of British Industry (CBI), (2001).

Cooke P. (1992), Regional innovation systems: competitive regulation in the new Europe. "Geoforum", no 23, p. 365-382.

Cooke P. (2001), Regional innovation systems, clusters and the knowledge economy, "Industrial \& Corporate Change", no 10, p. 945-974.

Cooke P., Heidenreich M., Braczyk H. (2004), Regional Innovation Systems, Second Edition, Routledge, London.

Cooke P., Leydesdorff L. (2006), Regional Development in the Knowledge-Based Economy: The Construction of Advantage, "Journal of Technology Transfer", January, vol. 31, Issue 1, p. $5-15$.

De la Mothe J., Mallory G. (2003), Industry-Government Relations in a Knowledge-Based Economy: the Role of Constructed Advantage, PRIME Discussion Paper 02-03, University of Ottawa: Program of Research in Innovation Management \& Economy (2003).

Desai R. M., Vreeland J. R. (2011), Global Governance in a Multipolar World: The Case for Regional Monetary Funds, "International Studies Review", no 13, March, p. 109-121.

Dunning J. (ed.), (2000), Regions, Globalisation \& the Knowledge-Based Economy, Oxford University Press, Oxford.

"Economic Bulletin" (2002).

Etzkowitz H., Leydesdorff L. (1998), The Endless Transition: A "Triple Helix" of University-Industry-Government Relations, "Minerva", no 36, p. 203-208.

Foray D., Freeman C. (1993), Technology and the Wealth of Nations: The Dynamics of Constructed Advantage, Pinter, London.

Freeman C. (1987), Technology Policy and Economic Performance: Lessons from Japan, Pinter, London.

Freeman C. (1988), Japan, a New System of Innovation, in: Technical Change and Economic Theory. eds. G. Dosi, C. Freeman, R. R. Nelson, G. Silverberg, L. Soete, Pinter, London, p. 31-54.

Fukuda-Parr S. (2011), Theory and Policy in International Development: Human Development and Capability Approach and the Millenium Development Goals, "International Studies Review", no 13, March, p. 122-132. 
Growth, Competitiveness and Jobs Priorities for the European Semester 2013 (2013), Presentation of

J. M. Barroso, President of the European Commission to the European Council of 14-15

March 2013, http://ec.europa.eu/news/pdf/sg.2013-00286-01-04-eu.tra-00.pdf, 24.01.2014.

Hayek F. (1945), The use of knowledge in society, “American Economic Review”, no 35, p. 519-530.

Hayek F. (1948), Economics and knowledge, in: Individualism and Economic Order, University of Chicago Press, Chicago.

Huges B. B., Irfan M. T. (2008), Assessing Strategies for Reducing Global Poverty, in: North and South in the World Political Economy, eds. Reuveny, W. R. Thompson, Blackwell Publishing Ltd., Malden USA-Oxford UK-Carlton Victoria Australia.

Krugman P. (1995), Development, Geography \& Economic Theory, Cambridge, MIT Press.

Leydesdorff L. (1994), Epilogue, in: Evolutionary Economics and Chaos Theory: New Directions for Technology Studies, eds. L. Leydesdorff, P. Van den Besselaar, Pinter, London-New York, p. $180-192$.

Leydesdorff L. (1995), The Challenge of Scientometrics: The Development, Measurement, and Self-Organization of Scientific Communications, DSWO Press, Leiden University, Leiden. http://www.upublish.com/books/leydesdorff-sci.htm.

Lundvall B.-A. (1988), Innovation as an Interactive Process: From User-Producer Interaction to the National System of Innovation, in: Technical Change and Economic Theory, eds. G. Dosi,

C. Freeman, R. Nelson, G. Silverberg, L. Soete, Pinter, London, p. 349-369.

Lundvall B.-A. (ed.), (1992), National Systems of Innovation, Pinter, London.

Marshall A. (1916), Principles of Economics, Macmillan, London.

Nelson R. R. (ed.), (1982), Government and Technical Progress: A Cross-Industry Analysis. Pergamon, New York.

Nelson R. R. (ed.), (1993), National Innovation Systems: A comparative study, Oxford University Press, Oxford-New York.

Nelson R. R., Winter S. G. (1982), An Evolutionary Theory of Economic Change, Belknap Press of Harvard University Press, Cambridge, MA

Nonaka I., Takeuchi H. (1995), The Knowledge-Creating Company, Oxford University Press, Oxford. Ohlin B. (1993), Interregional and International Trade, Harvard Business Press, Cambridge.

Pavitt K. (1984), Sectoral patterns of technical change: towards a theory and a taxonomy, "Research Policy", no 13, p. 343-373.

Penrose E. (1959), The Theory of the Growth of the Firm, Oxford University Press, Oxford.

Penrose E. (1995), The Theory of the Growt h of the Firm, Third Edition, Oxford University Press, Oxford.

Porter M. (1990), The Competitive Advantage of Nations, The Free Press, New York.

Porter M. (1998), On Competition, Harvard Business School Press, Boston.

Rosenberg N. (1976), Perspectives on Technology, Cambridge University Press, Cambridge.

Sahal D. (1981), Patterns of Technological Innovation, Addison Wesley, Reading, MA.

Sahal D. (1985), Technological Guideposts and Innovation Avenues, "Research Policy", no 14. p. $61-82$.

Schumpeter J. (1911), The Theory of Economic Development, Oxford University Press, Oxford.

SEC, 1428 (2011), final, vol. 1, Commission Staff Working Paper Executive Summary of the Impact Assessment Accompanying the Communication from the Commission "Horizon 2020 - The Framework Programme for Research and Innovation", Brussels, 30.11.2011.

Teece D., Pisano G. (1996), The dynamic capabilities of firms: an introduction, "Industrial \& Corporate Change", no 3, p. 537-556. 
Wibbels E., Ahlquist J. S. (1996), Development, Trade and Social Insurance, "International Studies Quarterly, Journal of the International Studies Association”, vol. 55, no 1, March, p. 125-149.

Whitley R. D. (1984), The Intellectual and Social Organization of the Sciences, Oxford University Press, Oxford.

Wojnicka E. (2008), Interactions in the innovation process as a factor of competitiveness of companies, http://www.4pm.pl/artykul/interakcje_w_procesie_innowacyjnym_jako_czynnik_konkurencyjności_przedsiebiorstw_czesc_1-37-54.html, 2009,1.

\begin{abstract}
Summary
The main aim of this paper is an analysis of the region in general form and to look at innovation and knowledge in the European Union's economic growth and social security strategy. The research objectives here encompass the presentation of the innovation system and knowledge in promoting entrepreneurship, the theoretical concept of the innovation system and process at the level of the region, the knowledge-based economy, constructed advantage, the constructed advantage provided by the Triple Helix model, Europe 2020 strategy, Innovation Union and Horizon 2020 as the financial instruments implemented by the Innovation Union. An important result of the research is the conclusion that in the innovation process the connections between science (universities), market (industry) and government are very important. There is a positive dependence between innovation activities and the effectiveness of the innovation process. More interaction and cooperation can be observed on the regional than on the state level. The new programmes of scientific and innovation research, Europe 2020 and the Innovation Union, are very important factors in the strategy of the European Union's economic growth and social security.
\end{abstract}

Key words: Region, innovation system, knowledge-based economy, constructed advantage, Europe 2020

\title{
Region, innowacje i wiedza w strategii wzrostu gospodarczego i bezpieczeństwa socjalne- go Unii Europejskiej
}

\section{Streszczenie}

Głównym celem artykułu jest analiza regionu w ujęciu ogólnym i przedstawienie innowacji oraz wiedzy w strategii wzrostu i bezpieczeństwa socjalnego Unii Europejskiej. Przedmiot badań obejmuje przedstawienie systemu innowacyjnego i wiedzy w promocji przedsiębiorczości, teoretycznej koncepcji systemu i procesu innowacyjnego na poziomie regionu, gospodarki opartej na wiedzy, korzyści strukturalnych, korzyści strukturalnych wynikających z zastosowania modelu Potrójnej Helisy (Spirali), strategii Europa 2020, Unii Innowacyjnej i Horyzontu 2020 jako instrumentu finansowego wprowadzania Unii Innowacyjnej. Istotnym rezultatem badawczym jest konkluzja, że w procesie innowacyjnym bardzo ważne są powiązania między nauką (uniwersytetami), rynkiem (przedsiębiorstwami) i instytucjami zarządzającymi. Istnieje pozytywna współzależność między działalnością innowacyjną a efektywnością procesu innowacyjnego. Więcej wzajemnych powiązań i współpracy obserwuje się na poziomie regionu niż na poziomie państwa. Nowe programy badań i innowacji - Europa 2020 i Unia Innowacyjna są bardzo ważnymi czynnikami strategii wzrostu gospodarczego i bezpieczeństwa socjalnego Unii Europejskiej.

Slowa kluczowe: region, system innowacyjny, wiedza oparta na gospodarce, Europa 2020 
